\title{
On the synonymy of the genera Collis Seo, 2018 and Erigomicronus Tanasevitch, 2018 (Arachnida: Aranei)
}

\author{
О синонимии родов Collis Seo, 2018 и Erigomicronus \\ Tanasevitch, 2018 (Arachnida: Aranei)
}

\begin{abstract}
Andrei V. Tanasevitch
A.В. Танасевич

A.N. Severtsov Institute of Ecology and Evolution, Russian Academy of Sciences, Leninsky prospekt 33, Moscow 119071, Russia. E-mail: tanasevitch@gmail.com

Институт проблем экологии и эволюции им. А.Н. Северцова РАН, Ленинский проспект 33, Москва 119071, Россия.
\end{abstract}

KEY WORDS: taxonomy, Araneae, spiders, Erigoninae.

КЛЮЧЕВЫЕ СЛОВА: таксономия, Araneae, пауки, Erigoninae.

ABSTRACT. The genus Collis Seo, 2018, syn.n., is considered as a subjective junior synonym of Erigomicronus Tanasevitch, 2018. A revised diagnosis of Erigomicronus is presented. The genus currently contains five species: Erigomicronus flavus (Seo, 2018), E. pusillus (Seo, 2018), E. silvaticus (Seo, 2018), all comb.n. ex Collis, all from Korea, E. lautus (Saito, 1984) from Japan, and E. longembolus (Wunderlich et Li, 1995) from the Liaoning Province, China and the Maritime Province, Russia.

How to cite this paper: Tanasevitch A.V. 2021. On the synonymy of the genera Collis Seo, 2018 and Erigomicronus Tanasevitch, 2018 (Arachnida: Aranei) // Arthropoda Selecta. Vol.30. No.2. P.257-258. doi: 10.15298/arthsel.30.2.13

РЕЗЮМЕ. Род Collis Seo, 2018, syn.n. признан младшим субъективным синонимом Erigomicronus Tanasevitch, 2018. Для рода Erigomicronus приведён обновлённый диагноз. В настоящее время род содержит пять видов: Erigomicronus flavus (Seo, 2018), E. pusillus (Seo, 2018), E. silvaticus (Seo, 2018), все comb.n. из Collis, все из Кореи, E. lautus (Saito, 1984 ) из Японии и E. longembolus (Wunderlich et Li, $1995)$ из провинции Ляонин (Китай) и Приморского края (Россия).

\section{Introduction}

The genus Erigomicronus Tanasevitch, 2018 was originally established for the East Asian Oreonetides longembolus Wunderlich et Li, 1995 (the type species) and the Japanese Maro lautus Saito,1984 [Tanasevitch, 2018]. The genus Collis Seo, 2018 was erected for three Korean species, i.e. C. flavus Seo, 2018 (the type species), C. pusillus Seo, 2018, and C. silvaticus Seo, 2018 [Seo, 2018].

An analysis of the somatic and genital structures of the type species of both genera shows that they are undoubtedly congeneric. Moreover, all species of both genera show a similar habitus, the same chaetotaxy and trichobothriotaxy, and are characterized by the same structure of the genitalia, differing from one another by certain details of genitalic conformation alone.

Incidentally, both papers establishing the erigonine spider genera Erigomicronus and Collis appeared almost simultaneously, with a time gap of a few days only. The description of the genus Erigomicronus was published in "Zootaxa", volume 4524, number 2, on November $21^{\text {st }}, 2018$ (doi:10.11646/zootaxa.4524.2.8). That of the genus Collis appeared nine days later, on November $30^{\text {th }}, 2018$, in the "Journal of Species Research", volume 7, number 4 (doi:10.12651/JSR. 2018.7.4.251). Thus, the name Erigomicronus has a time priority, however minor, over Collis, and the genus Collis Seo, 2018, syn.n., becomes a subjective junior synonym of Erigomicronus Tanasevitch, 2018.

\section{Taxonomy}

Erigomicronus Tanasevitch, 2018

Erigomicronus Tanasevitch, 2018: 246.

Collis Seo, 2018: 279, syn.n.

DIAGNOSIS. The genus contains small and pale erigonines, with a total length of $1.10-1.40 \mathrm{~mm}$. The carapace is unmodified in both sexes. The leg chaetotaxy formula is 2.2.2.1, lateral tibial spines are absent; the metatarsi are spineless. Metatarsi I-III each with a trichobothrium. TmI $0.30-0.40$.

Males are characterized by the following combination of genitalic characters:

1. Paracymbium strongly modified, devoid of pockets and carrying several outgrowths not typical of erigonines.

2. Presence of a unique, sclerotized, column-like process, a special, very long, ventral outgrowth on the distal suprategular apophysis (see Tanasevitch [2018]). This process performs the role of a column, a short membranous tube through which the sperm duct passes from the distal suprategular apophysis to the embolic division. As a possible 
alternative, this column-like process is just a sclerotized column of an unusually great length.

3. Embolic division highly complex: a large and strongly modified radix, a whip-shaped embolus, and a highly developed convector, i.e. an additional palpal sclerite that protects and supports the slender and very long embolus. This sclerite was erroneously termed by Saito [1984], Wunderlich, Li [1995] and Seo [2018] as a lamella characteristica. Originally, the term "lamella characteristica" was coined by Kulczyñski [1898], and it can be only applied to a particular sclerite in the embolic division in the subfamily Micronetinae (see Saaristo \& Tanasevitch [1996]).

Females are diagnosed by the presence of a peculiar scape-like projection in the epigyne which resembles a micronetine stretcher.

TAXONOMIC REMARKS. Due to two unique features, i.e. the column-like process in the male palp and the scapelike projection in the epigyne, the taxonomic position of Erigomicronus seems to be quite isolated within the known erigonines. Based on a slight similarity in structure of the embolic division, it can only be brought closer to the erigonine genus Houshenzinus Tanasevitch, 2006 (for details, see Tanasevitch [2018]). The epigyne in the representatives of Erigomicronus is very similar to that in the micronetine genera Maro O. Pickard-Cambridge, 1906 and Oreonetides Strand, 1901. Apparently, this similarity is only superficial, being based just on similar shapes of a protruding anterior wall of the epigyne, as well as the presence of a scape-like projection. Unlike the latter, this "scape-like projection" in Maro and Oreonetides is a stretcher, an apical part of the true micronetine scape sensu Saaristo, Tanasevitch [1996].

SPECIES INCLUDED. The genus currently contains five species: Erigomicronus flavus (Seo, 2018), E. pusillus (Seo, 2018) and E. silvaticus (Seo, 2018), all comb.n. ex Collis, all from Korea [Seo, 2018], E. lautus (Saito, 1984) from Japan [Saito, 1984] and E. longembolus (Wunderlich et $\mathrm{Li}, 1995)$ known from the Liaoning Province of China
[Wunderlich, Li, 1995] and the Maritime Province, Russia [Eskov, 1991, Marusik et al., 2016].

Acknowledgements. I am deeply grateful to Sergei Golovatch (Moscow) for editing an early draft of this paper.

\section{References}

Eskov K.Yu. 1991. [On the taxonomy and zoogeography of the spider genera Maro and Oreonetides (Aranei, Linyphiidae)] // Zoologicheskii zhurnal. Vol.70. No.4. P.45-54 [in Russian, with an abstract in English].

Kulczyński W. 1898. Symbola ad faunam aranearum Austriae inferioris cognoscendam // Rozprawy i sprawozdania z posiedzeń Wydziału Matematyczno Przyrodniczego Akademji Umiejętnośći, Kraków. T.36. P.1-114.

Marusik Yu.M., Omelko M.M., Koponen S. 2016. Rare and new for the fauna of the Russian Far East spiders (Aranei) // Far Eastern Entomologist. No.317. P.1-15.

Saaristo M.I., Tanasevitch A.V. 1996. Redelimitation of the subfamily Micronetinae Hull, 1920 and the genus Lepthyphantes Menge, 1866 with descriptions of some new genera // Berichte des Naturwissenschaftlich-Medizinischen Vereins in Innsbruck. Bd.83. P.163-186.

Saito H. 1984. Descriptions of four new species of the soil dwelling linyphiine spiders (Araneae: Linyphiidae) from the Kyushu and Kanto Districts // Edaphologia. Vol.31. P.1-8.

Seo B.K. 2018. New species and records of the spider families Pholcidae, Uloboridae, Linyphiidae, Theridiidae, Phrurolithidae, and Thomisidae (Araneae) from Korea // Journal of Species Research. Vol.7. No.4. P.251-290.

Tanasevitch A.V. 2018. A new, remarkable erigonine spider genus from eastern Asia (Araneae, Linyphiidae) // Zootaxa. Vol.4524. No.2. P.245-250.

Wunderlich J., Li S.Q. 1995. Three new spider species and one new genus (family Linyphiidae) from China (Arachnida: Araneae) // Beiträge zur Araneologie. Bd.4. S.335-342.

Responsible editor K.G. Mikhailov 